\title{
Stawomir CHOMICKI
}

Uniwersytetu w Bialymstok ${ }^{1}$

Wydzial Prawa, Katedra Prawa Karnego i Kryminologii

slawomirchomicki@o2.pl

https://orcid.org/0000-0003-4358-9786

https://doi.org/10.34739/dsd.2021.02.09

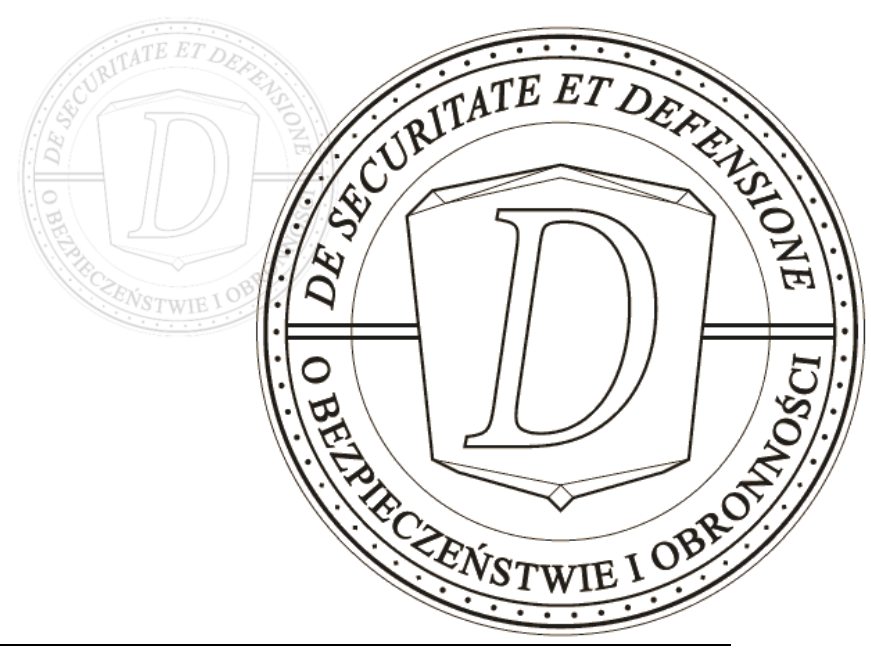

\section{ODPOWIEDZIALNOŚĆ KARNA I DYSCYPLINARNA ŻOŁNIERZA I FUNKCJONARIUSZA W ŚWIETLE ZASADY NE BIS IN IDEM}

\begin{abstract}
ABSTRAKT: Pojawienie się w systemie prawa wojskowych przepisów dyscyplinarnych, wprowadzających kategorię tzw. czynu stykowego (tj. czynu, który jest wojskowym przewinieniem dyscyplinarnym realizującym jednocześnie znamiona czynu zabronionego, penalizowanego w innej ustawie, np. w ustawie z 06.06.1997 r., Kodeks karny ) uruchomiło szereg pytań o wzajemną relację zachodzącą między posiadającą represyjny charakter odpowiedzialnością karną, a quasi-represyjną wojskową odpowiedzialnością dyscyplinarną. Do kategorii czynu stykowego expressis verbis odnosi się przepis art. 17 ust. 1 oraz art. 17 ust. 2 pkt 2-3 ustawy z 09.10.2009 r. o dyscyplinie wojskowej . Popełnienie przez żołnierza wojskowego przewinienia dyscyplinarnego, które jednocześnie realizuje znamiona przestępstwa penalizowanego w k.k., daje możliwość podwójnego (tj. karnego i dyscyplinarnego) ukarania żołnierza za de facto ten sam czyn. Dlatego zastanowić się trzeba, czy taka praktyka czyni zadość konstytucyjnej zasadzie ne bis in idem (zakazującej ponownego karania osoby za ten sam czyn), czy też może wręcz przeciwnie - praktyka ta godzi w standardy konstytucyjne. Analiza dokonana w niniejszym artykule jest próbą udzielenia odpowiedzi na to pytanie. Rozważania mają charakter dogmatyczno-historyczny przy zastosowaniu metody wykładni systemowej i językowej.
\end{abstract}

SŁOWA KLUCzOWE: odpowiedzialność karna, odpowiedzialność dyscyplinarna, zasada ne bis in idem, zakaz podwójnego karania, żołnierz

\section{CRIMINAL AND DISCIPLINARY LIABILITY OF A SOLDIER AND AN OFFICER IN THE LIGHT OF THE NE BIS IN IDEM PRINCIPLE}

ABSTRACT: The appearance in the legal system of military disciplinary regulations introducing the category of the so-called a contact act (i.e. an act that is a military disciplinary offense that simultaneously fulfills the features of a prohibited act, penalized in another act, e.g. in the Act of June 6, 1997, the Penal Code) triggered a number of questions about the mutual relationship between the repressive nature of criminal and quasi-repressive military disciplinary liability. The category of a contact act expressis verbis refers to the provision of Art. $17 \mathrm{sec} .1$ and art. $17 \mathrm{sec} .2$ points 2-3 of the Act of 09/10/2009 on Military Discipline. Committing a military disciplinary offense by a military soldier, which at the same time carries the features of an offense penalized in the Criminal Code, gives the possibility of double (i.e. criminal and disciplinary) punishment of a soldier for the same act in fact. Therefore, it is necessary to consider whether such practice makes ne bis in idem

${ }^{1}$ University of Białystok; Poland. 
(prohibiting repeated punishment of a person for the same act) quite a constitutional principle; or, on the contrary, this practice violates constitutional standards? The analysis made in this article is an attempt to answer this question. The considerations are dogmatic and historical in nature, using the method of systemic and linguistic interpretation.

KEYWORDS: criminal liability, disciplinary liability, ne bis in idem principle, prohibition of double punishment, soldier

\section{WPROWADZENIE}

Możliwość podwójnego (tj. karnego i dyscyplinarnego) ukarania żołnierza za wojskowe przewinienie dyscyplinarne, które jest jednocześnie innym czynem karalnym (czyli jest tzw. czynem stykowym) bezpośrednio akcentuje treść przepisu art. 17 ust. 1 u.d.w. Zgodnie z jego brzmieniem żołnierz ponosi odpowiedzialność dyscyplinarną niezależnie od odpowiedzialności kreowanej na gruncie innych przepisów. Stąd żołnierz za czyn pozostający w związku z jego służbą może ponieść odpowiedzialność karną i dyscyplinarną ${ }^{2}$ (jednocześnie lub sekwencyjnie). Tytułem zasygnalizowania zauważyć należy, że analogiczne rozwiązanie przyjęto także w przepisach mundurowych dotyczących funkcjonariuszy: SG, ABW, AW, Policji, SKW, SWW, CBA, SW czy SP ${ }^{3}$.

Do kategorii czynu stykowego (który jest jednocześnie wojskowym przewinieniem dyscyplinarnym i przestępstwem/wykroczeniem) expressis verbis odnoszą się również pozostałe jednostki redakcyjne przepisu art. 17 u.d.w. tj. ust. 2 pkt 2-3 tego artykułu. Poczynić jednak należy pewne zastrzeżenie. Do podwójnego (tj. karnego i dyscyplinarnego) ukarania żołnierza nie dojdzie w sytuacji wskazanej w przepisie art. 17 ust. 2 pkt 2 u.d.w. (tj. przy przestępstwach wojskowych ściganych na wniosek dowódcy jednostki wojskowej lub przy wykroczeniach wojskowych ściganych na żądanie dowódcy jednostki wojskowej). Zgodnie z treścią wskazanego przepisu w tej sytuacji możliwość dyscyplinarnego ukarania żołnierza (który popełnił

\footnotetext{
${ }^{2}$ Np. żołnierza, który znieważył przełożonego, można ukarać i karnie (art. 347 k.k.), i dyscyplinarnie (jeżeli przedmiotowe znieważenie miało związek ze służbą wojskową).

${ }^{3}$ Vide np.: art. 134 ustawy z 12.10.1990, o Straży Granicznej, t.j. Dz.U. 2021, poz. 1728 (dalej: u.s.gra.): „Funkcjonariusz ponosi odpowiedzialność dyscyplinarną za popełnione przestępstwa i wykroczenia - niezależnie od odpowiedzialności karnej"; art. 144 ustawy z 24.05.2002, o Agencji Bezpieczeństwa Wewnętrznego oraz Agencji Wywiadu, t.j. Dz.U. 2020, poz. 2320 (dalej: u.a.b.w.a.w): „Funkcjonariusz, niezależnie od odpowiedzialności karnej, ponosi odpowiedzialność dyscyplinarną za popełnione przestępstwa i wykroczenia"; art. 132 ustawy z 06.04.1990, o Policji, t.j. Dz.U. 2021, poz. 1882 (dalej: u.pol.): „Policjant ponosi odpowiedzialność dyscyplinarną za popełnione przestępstwa i wykroczenia - niezależnie od odpowiedzialności karnej”; art. 105 ustawy z 09.06.2006, o służbie funkcjonariuszy Służby Kontrwywiadu Wojskowego oraz Służby Wywiadu Wojskowego, t.j. Dz.U. 2021, poz. 1362 (dalej: u.s.k.w.s.w.w.): „Funkcjonariusz, niezależnie od odpowiedzialności karnej, ponosi odpowiedzialność dyscyplinarną za popełnione przestępstwa i wykroczenia"; art. 106 ustawy z 09.06.2006, o Centralnym Biurze Antykorupcyjnym, t.j. Dz.U. 2021, poz. 1671 (dalej: u.c.b.a.): „Funkcjonariusz, niezależnie od odpowiedzialności karnej, ponosi odpowiedzialność dyscyplinarną za popełnione przestępstwa i wykroczenia"; art. 230 ust. 4 ustawy z 09.04.2010, o Służbie Więziennej, t.j. Dz. U. 2021, poz. 1728 (dalej: u.s.więz.): „Czyn stanowiący przewinienie dyscyplinarne, wypełniający jednocześnie znamiona przestępstwa, wykroczenia, przestępstwa skarbowego, wykroczenia skarbowego podlega odpowiedzialności dyscyplinarnej niezależnie od odpowiedzialności karnej lub karnej skarbowej”; art. 115 ust. 2 ustawy z 24.08.1991, o Państwowej Straży Pożarnej, t.j. Dz.U. 2021, poz. 1728 (dalej: u.s.poż.): „Strażak ponosi odpowiedzialność dyscyplinarną za popełnione przestępstwa i wykroczenia - niezależnie od odpowiedzialności karnej”.
} 
czyn stykowy) zależy od uprzedniej rezygnacji przez dowódcę jednostki wojskowej z przysługującego mu uprawnienia do złożenia wniosku lub żądania o ściganie ${ }^{4}$.

Zupełnie inna sytuacja zachodzi natomiast, gdy wojskowe przewinienie dyscyplinarne żołnierza jako czyn stykowy jest również: przestępstwem wojskowym ściganym z urzędu lub czynem zabronionym wskazanym w przepisie art. 17 ust. 2 pkt 3 u.d.w. (tj. przestępstwem lub wykroczeniem albo przestępstwem lub wykroczeniem skarbowym). Wówczas możliwość podwójnego (tj.karnego i dyscyplinarnego) jednoczesnego lub sekwencyjnego ukarania żołnierza za popełniony przez niego czyn stykowy (będący jednocześnie wojskowym przewinieniem dyscyplinarnym i np. przestępstwem wojskowym ściganym z urzędu) jest jak najbardziej realna.

Wojskowa odpowiedzialność dyscyplinarna żołnierza (jak i odpowiedzialność dyscyplinarna wskazanych wyżej przedstawicieli służb mundurowych) jest zatem odpowiedzialnością autonomiczną i niezależną od odpowiedzialności kreowanej na gruncie innych ustaw (np. k.k. ${ }^{5}$ ). Innymi słowy, żołnierz może być pociągnięty do wojskowej odpowiedzialności dyscyplinarnej niezależnie od tego, czy toczy się już wobec niego jakiekolwiek postępowanie (np. karne) czy też nie (zob.: art. 17 ust. 2 pkt 2 u.d.w.).

Zdawać by się mogło, że wskazana w treści przepisu art. 17 ust. 1 i ust. 2 pkt 3 u.d.w. możliwość jednoczesnego lub sekwencyjnego prowadzenia względem żołnierza za czyn, będący czynem stykowym, dwóch różnych postępowań (np. karnego i dyscyplinarnego) narusza konstytucyjną zasadę ne bis in idem - posiadającą na płaszczyźnie ustawodawstwa krajowego bezwzględny charakter i stanowiącą ujemną przesłankę procesową ${ }^{6}$. Nie jest to jednak stanowisko słuszne. Dla wykazania racji w tym zakresie za przedmiot badania przyjęto zasadę ne bis in idem, jej standardy jednak odniesiono wyłącznie do odpowiedzialności karnej i dyscyplinarnej żołnierza. Celem badawczym jest ocena konstytucyjności jednoczesnego lub sekwencyjnego prowadzenia postepowań (karnych i dyscyplinarnych) wobec żołnierza. Mający natomiast formę pytania ,rozstrzygnięcia"7 problem badawczy skonkretyzowano jako: Czy jednoczesne lub sekwencyjne prowadzenie względem żołnierza postępowania karnego i dyscyplinarnego za ten sam czyn narusza konstytucyjną gwarancję dotyczącą zakazu podwójnego karania?

\footnotetext{
${ }^{4} \mathrm{~W}$ tym miejscu wskazać należy, że ukaranie dyscyplinarne żołnierza - realizowane po uprzedniej rezygnacji przez dowódcę jednostki wojskowej z przysługującego mu uprawnienia do złożenia wniosku lub żądania o ściganie - nie wyklucza w sposób definitywny możliwości pociągnięcia do odpowiedzialności karnej żołnierza. Vide art. 660 ustawy z 06.06.1997, Kodeks postępowania karnego, t.j. Dz.U. 2021, poz.1023 (dalej: k.p.k.).

${ }^{5}$ Vide m.in.: Wyrok WSA w Warszawie z 15.11.2006, II SA/Wa 1344/06, wyrok WSA w Warszawie z 17.01.2006, II SA/Wa 1755/05, LEX nr 194440: „Postępowanie dyscyplinarne jest postępowaniem samodzielnym i niezależnym od postępowania karnego, a (...) [podmiot] podlega odpowiedzialności dyscyplinarnej, niezależnie od odpowiedzialności karnej”; czy wyrok WSA w Warszawie z 15.04.2004, II SA/Wa 1561/03, LEX nr 150843: „Postępowanie dyscyplinarne jest postępowaniem samodzielnym i niezależnym od postępowania karnego (...). Ta dwutorowość obu postępowań oznacza, iż w toku każdego z nich konieczne jest czynienie własnych ustaleń oraz ich własnej oceny. Niedopuszczalne jest ograniczenie postępowania dowodowego prowadzonego przez organ administracji publicznej do dowodów zgromadzonych w innym, odrębnym postępowaniu".

${ }^{6}$ Vide art. $17 \S 1$ pkt 7 ustawy z 06.06.1997, Kodeks postępowania karnego, t.j. Dz.U. 2021, poz.1023 (dalej: k.p.k.).

${ }^{7}$ M. Łobocki, Wprowadzenie do metodologii badań pedagogicznych, Kraków 2007, s.126.
} 


\section{KONSTYTUCYJNA ZASADA NE BIS IN IDEM A CELE ODPOWIEDZIALNOŚCI KARNEJ I DYSCYPLINARNEJ}

Analiza rozstrzygnięć legislacyjnych Trybunału Konstytucyjnego nie pozostawia wątpliwości, że stanowiąca jeden z elementów państwa prawa zasada ne bis in idem urzeczywistnia zasadę sprawiedliwości społecznej ${ }^{8}$ oraz współtworzy katalog fundamentalnych zasad prawa karnego. Dlatego wszelkie praktyki zmierzające do wyposażenia organu władzy publicznej w możliwość dwukrotnego stosowania środka o charakterze represyjnym względem tej samej osoby za ten sam czyn i w tym samym celu, postrzegać należy w kategorii naruszenia reguł konstytucyjnych ${ }^{9}$.

Na płaszczyźnie postępowania karnego sensu largo zakaz „podwójnego karania” rozumieć należy jako gwarancję niepociągania ponownie do odpowiedzialności karnej sprawcy za ten sam czyn zabroniony. Choć zastosowanie komentowanej zasady w odniesieniu do prawa karnego nie budzi żadnych wątpliwości, to dyskusję wywołuje już konieczność jednoczesnego lub sekwencyjnego zastosowania wobec żołnierza unormowań prawnokarnych i unormowań dyscyplinarnych. Usystematyzowaniu stanowiska w tym zakresie pomóc może analiza celu/celów, jakim służy odpowiedzialność karna oraz wojskowa odpowiedzialność dyscyplinarna. $\mathrm{W}$ państwie prawa nie jest bowiem dopuszczalne dwukrotne karanie tej samej osoby za to samo zachowanie w różnych postępowaniach, lecz w tym samym celu.

Funkcjonowanie na płaszczyźnie odpowiedzialności represyjnej sensu largo kilku jej rodzajów (przy czym odpowiedzialność karna ma charakter stricte represyjny, wojskowa zaś odpowiedzialność dyscyplinarna quasi-represyjny ${ }^{10}$ ) implikuje konieczność występowania zupełnie innego (głównego) celu każdego z tych postępowań ${ }^{11}$.

Jednolite stanowisko doktryny prawa karnego co do celów odpowiedzialności karnej (tj. jej celu: ochronnego, sprawiedliwościowego i prewencyjnego $)^{12}$ powoduje, że kwestia ta nie będzie poddana głębszej analizie. Więcej uwagi wymaga natomiast analiza celu/celów wojskowej odpowiedzialności dyscyplinarnej. Zagadnienie to dotychczas, przynajmniej w naszej literaturze przedmiotu, doczekało się nielicznych opracowan ${ }^{13}$.

Pomocnym przy określeniu celu wojskowej odpowiedzialności dyscyplinarnej może okazać się analiza historyczna regulacji dyscyplinarnych obowiązujących uprzednio ( $\mathrm{tj}$. do momentu wejścia w życie u.d.w. z 2009 r.). Na przestrzeni lat aspekt wychowawczy unormowań

\footnotetext{
${ }^{8}$ Vide wyrok TK z 8.10.2002, sygn. K 36/00, OTK-A 2002, z. 5, poz. 63.

${ }^{9}$ Wyrok TK z 3.11.2004, sygn. K 18/03, OTK-A 2004, z. 10, poz. 103.

10 Więcej na ten temat: A. Ziółkowska, Odpowiedzialność karna a odpowiedzialność dyscyplinarna w wojsku zagadnienia materialnoprawne I, Warszawa 2020, s. 24-28, 66-72.

${ }^{11}$ Zdaniem M. Rogalskiego postępowania dyscyplinarne i karne „mają innych adresatów i pełnią odmienne funkcje”, z czym należy się zgodzić; więcej: M. Rogalski, Odpowiedzialność dyscyplinarna prokuratorów a odpowiedzialność karna. Zagadnienia wybrane [w:] H. Zięba-Załucka (red.), M. Kijowski (red.) Godność obywatela, urzędu i instytucji. Zmiany ustrojowe Prokuratury RP, Rzeszów 2005, s. 107.

${ }^{12}$ Vide R. Giętkowski, Odpowiedzialność dyscyplinarna w prawie polskim, Gdańsk 2013, s. 89-130.

${ }^{13}$ Vide A. Ziółkowska, Odpowiedzialność karna a odpowiedzialność dyscyplinarna ..., op. cit., s. 55-66.
} 
dyscyplinarnych akcentowany był expressis verbis w rozwiązaniach rangi ustawowej czy (towarzyszących im na zasadzie uzupełnienia) aktach okołoustawowych (mających postać np. regulaminów dyscyplinarnych). Wychowawczy cel przepisów dyscyplinarnych (a co za tym idzie i wojskowej odpowiedzialności dyscyplinarnej) wskazano m.in.:

- $\quad$ w art. 2 $\$ 2$ dekretu z 26.06.1945 r. ${ }^{14}$, w którym zobowiązano przełożonych do wychowywania żołnierzy w duchu przestrzegania zasad wskazanych w art. 1 tegoż dekretu;

- w pkt 27 ppkt 1 Regulaminu Dyscyplinarnego Sił Zbrojnych PRL z 1959 r. ${ }^{15}$;

- w pkt 35 i 40 Regulaminu Dyscyplinarnego z 1963 r. ${ }^{16}$ (w obydwu przypadkach podkreślono wychowawczy charakter kary dyscyplinarnej);

- $\quad$ w art. 11 ust. 2 ustawy z 21.05.1963 r. ${ }^{17}$ (statuującym zasadę, iż przewinienie dyscyplinarne nie zawsze musi kończyć się ukaraniem, ponieważ przełożony posiadał prawo zastosowania w pierwszej kolejności środków wychowawczych niezbędnych do utrzymania dyscypliny wojskowej).

Wskazane tradycje legislacyjne kontynuowane są również na gruncie obecnie obowiązującej u.d.w. z 2009 r. (zob.: art. 20 ust. 1 u.d.w.).

Wprawdzie merytoryczny zakres wojskowej odpowiedzialności dyscyplinarnej obejmuje w większości wypadków czyny relewantne z punktu widzenia prawa karnego ${ }^{18}$, to główny cel wojskowej odpowiedzialności dyscyplinarnej nie jest tożsamy z głównym celem odpowiedzialności karnej. To z kolei, w sytuacji zbiegu wojskowej odpowiedzialności dyscyplinarnej z odpowiedzialnością karną, przesądza o poszanowaniu nie tylko zasady ne bis in idem, lecz także zasady proporcjonalności wyrażonej w przepisie art. 31 ust. 3 ustawy z 2.04.1997 r., Konstytucja Rzeczypospolitej Polskiej ${ }^{19}$. Również i TK w jednym ze swoich wyroków wskazał, że: ,,deontologia postepowania dyscyplinarnego jest inna niż postępowania karnego. Łączy się ona przede wszystkim ze szczególnym charakterem niektórych zawodów oraz zasadami funkcjonowania konkretnych korporacji zawodowych. Ukształtowane w ich ramach reguły deontologiczne ukierunkowane są przede wszystkim na obronę honoru i dobra zawodu. (...) [Natomiast] odpowiednie stosowanie przepisów Kodeksu postępowania karnego nie oznacza, że postępowanie dyscyplinarne staje się postępowaniem karnym"20.

Między innymi dlatego nie należy podzielić stanowiska, zgodnie z którym represja miałaby stanowić główny cel wojskowej odpowiedzialności dyscyplinarnej. Rozpoznanie to jest

\footnotetext{
${ }^{14}$ Dekret z 26 czerwca 1945 r., Wojskowe przepisy dyscyplinarne, Dz. U. 1945, nr 37, poz. 219.

${ }^{15}$ Regulamin Dyscyplinarny Sił Zbrojnych PRL z 1959 r., zatwierdzony i wprowadzony w życie rozkazem Ministra Obrony Narodowej nr 30/MON z 28 lipca 1959 r.

${ }^{16}$ Regulamin Dyscyplinarny z 1963, zatwierdzony i wprowadzony w życie rozkazem Ministra Obrony Narodowej nr 57/MON z 19 października $1963 \mathrm{r}$.

${ }^{17}$ Ustawa z 21 maja 1963 r., o dyscyplinie wojskowej oraz o odpowiedzialności żołnierzy za przewinienia dyscyplinarne i za naruszenia honoru i godności żołnierskiej, Dz. U. 1963, nr 22, poz. 114.

${ }_{18}$ Vide W. Morański, Charakter prawny odpowiedzialności dyscyplinarnej członka korpusu stużby cywilnej, „Roczniki Administracji i Prawa”, Rok XIII, s. 251.

${ }^{19}$ Ustawa z 2.04.1997, Konstytucja Rzeczypospolitej Polskiej, t.j. Dz.U. 2009, poz. 946.

${ }^{20}$ Wyrok TK z 27.02.2001, sygn. K. 22/00, OTK ZU 2001, nr 3, s. 266-268.
} 
konsekwencją postrzegania prawa dyscyplinarnego jako części składowej prawa karnego ${ }^{21}$, co również nie jest zasadne, gdyż przepisy prawa dyscyplinarnego stanowią regulację prawną sui generis, zaś fakt, że mamy do czynienia ze zjawiskiem karania (w tym przypadku dyscyplinarnego), nie przesądza automatycznie, jakiemu celowi owo karanie ma służyć.

W literaturze przedmiotu przez cel wojskowej odpowiedzialności dyscyplinarnej rozumie się zarówno dążenie do poprawy zachowania osoby, która dopuściła się przewinienia dyscyplinarnego (a w sytuacji ostatecznej nawet zwolnienia jej z członkostwa w określonej formacji, w tym przypadku wojska ${ }^{22}$ ), jak i zdyscyplinowanie pozostałych członków danego kolektywu, tj. żołnierzy (poprzez wysłany sygnał ostrzegawczy o możliwości poniesienia prawnych konsekwencji ${ }^{23}$. Ramowe przybliżenie celów wojskowej odpowiedzialności dyscyplinarnej bezpośrednio akcentuje polaryzację zachodzącą między wojskową odpowiedzialnością dyscyplinarną a karną odpowiedzialnością, tj. odpowiedzialnościami, które jednocześnie lub synchronicznie może ponosić żołnierz za czyn, będący czynem stykowym. Podczas gdy cel odpowiedzialności karnej zmierza przede wszystkim do zapewnienia sprawiedliwej odpłaty za popełnione przestępstwo, to cel wojskowej odpowiedzialności dyscyplinarnej ukierunkowany jest na zapewnienie właściwego funkcjonowania określonej formacji. Zatem w sytuacji pociągnięcia żołnierza do odpowiedzialności karnej oraz wojskowej odpowiedzialności dyscyplinarnej (jednocześnie lub sekwencyjnie) za jeden czyn (wyczerpujący znamiona przestępstwa i będący jednocześnie przewinieniem dyscyplinarnym - tj. czyn stykowy) de facto dochodzi do konfrontacji: jednego z głównych celów odpowiedzialności karnej - sprawiedliwej odpłaty (realizowanego m.in. poprzez zastosowanie represji) z właściwym dla wojskowej odpowiedzialności dyscyplinarnej celem wychowawczym, widocznym w konieczności zapewnienia wśród członków danej formacji (wojska) określonych postaw, niezbędnych dla jej prawidłowego funkcjonowania (co sprzyja wzrostowi poziomu zaufania społecznego do tejże grupy) ${ }^{24}$. Dlatego cel wojskowej odpowiedzialności dyscyplinarnej (skonkretyzowany na wychowanie, a przez to i ochronę funkcjonowania danego kolektywu) nie jest tożsamy z celem odpowiedzialności karnej (polegającym na ochronie interesu. zarówno ogółu społeczeństwa, jak i poszczególnych jego osób poprzez zastosowanie instrumentów o charakterze głównie represyjnym $)^{25}$.

\footnotetext{
${ }^{21}$ Jak wskazuje M. Cieślak: ,prawo dyscyplinarne wprost postrzegać można za szczególną gałąź czy rodzajową odmianę prawa karnego"; M. Cieślak, Polskie prawo karne. Zarys systemowego ujęcia, Warszawa 1994, s. $22-23$.

${ }^{22}$ Przy czym możliwość usunięcia żołnierza ze służby (jako jedna z możliwych kar dyscyplinarnych - art. 24 ust 7 u.d.w.) nie stoi w opozycji do wyżej wskazanego celu, gdyż kara ta nie stanowi sama w sobie celu odpowiedzialności dyscyplinarnej, a jej zastosowanie determinuje: po pierwsze charakter przewinienia dyscyplinarnego, po drugie postawa - obwinionego żołnierza.

${ }^{23}$ Zob.: Z. Leoński, Odpowiedzialność dyscyplinarna w prawie Polski Ludowej, Pozná́ 1959, s. 56.

${ }^{24}$ Zob.: P. Skuczyński, Granice odpowiedzialności dyscyplinarnej, [w:] P. Skuczyński, P. Zawadzki, Odpowiedzialność dyscyplinarna. Podstawy, procedura i orzecznictwo $w$ sprawach studentów Uniwersytetu Warszawskiego 2000-2005, Warszawa 2008, s. 11, 14-15.

${ }^{25}$ Zob.: Z. Leoński, Odpowiedzialność dyscyplinarna w..., op. cit., s. 56.
} 


\section{KONSTYTUCYJNA ZASADA NE BIS IN IDEM A WYBRANE FUNKCJE ODPOWIE- DZIALNOŚCI KARNEJ I DYSCYPLINARNEJ}

Analogicznie jak w poprzedniej jednostce redakcyjnej, jednolite stanowisko doktryny prawa karnego, co do kwestii funkcji odpowiedzialności karnej (takich jak np. funkcja: represyjna ${ }^{26}$, ochronna czy sprawiedliwościowa) ${ }^{27}$, a także ramy niniejszego opracowania spowodowały, że wątek ten omówiono w ograniczonym zakresie. Optykę opracowania tej części artykułu skupiono natomiast głównie na analizie funkcji wojskowej odpowiedzialności dyscyplinarnej.

Wojskowa odpowiedzialność dyscyplinarna, łącząca w sobie normy prawa materialnego, ustrojowego i procesowego, jest kategorią sui generis ${ }^{28}$ o interdyscyplinarnym charakterze, gdyż znajduje się ona na pograniczu kilku gałęzi prawa jednocześnie ( $\mathrm{tj}$. prawa karnego, prawa pracy czy prawa administracyjnego).

Istnienie wojskowych przepisów dyscyplinarnych posiada wartość dodaną w przedmiocie kreowania zakresu ochrony, a tym samym swobody świadczenia służby wojskowej przez żołnierzy. Wprawdzie przesłanki wojskowej odpowiedzialności dyscyplinarnej posiadają charakter ogólny (gdyż w u.d.w. ustawodawca nie skonkretyzował zamkniętego katalogu wojskowych przewinień dyscyplinarnych), to jednak odpowiedzialność ta ,tworzy funkcję ochronną i w ten sposób zapewnia członkom danej (...) [zbiorowości] niezbędną swobodę i niezależność (...) [w ramach służby wojskowej]”29. W związku z tym ,określone jednostkowe zachowanie (...) uchybiające godności (...) [służby wojskowej] i podważające zaufanie niezbędne do (...) [prawidłowej jej realizacji] może prowadzić do (...) [usunięcia ze służby wojskowej] (...) w drodze postępowania dyscyplinarnego"30.

Funkcja ochronna realizowana $\mathrm{w}$ ramach wojskowej odpowiedzialności dyscyplinarnej ma charakter dwukierunkowy (inaczej niż przy odpowiedzialności karnej, gdzie funkcja ochronna nastawiona jest na zapewnienie ochrony społeczeństwa przed jednostką dla niego niebezpieczną, a wiec jednokierunkowo). Wojskowa odpowiedzialność dyscyplinarna, poprzez możliwość usunięcia dyscyplinarnego żołnierza ze służby, stoi na straży wartości relewantnych z punktu widzenia służby wojskowej (tj. poszanowania dyscypliny wojskowej, karności czy posłuchu dla przełożonych). Zabezpieczenie kolektywu wojskowego przed ingerencją organów zewnętrznych powoduje natomiast, że wojskowa odpowiedzialność dyscyplinarna zapewnia żołnierzom niezbędną do należytego pełnienia/odbywania służby wojskowej - swobodę oraz gwarancję niezależności w wykonywaniu ich obowiązków służbowych.

\footnotetext{
${ }^{26}$ Vide A. Błachnio-Parzych, Zbieg odpowiedzialności karnej i administracyjno-karnej jako zbieg reżimów odpowiedzialności represyjnej, Warszawa 2016, s. 42-50;

${ }^{27}$ Vide V. Konarska-Wrzosek, A. Marek, Prawo karne, Warszawa 2019, s. 14-17; J. Lachowski, A. Marek, Prawo karne. Zarys problematyki, Warszawa 2018, s. 25-27.

${ }^{28}$ Vide A. Ziółkowska, Odpowiedzialność karna a odpowiedzialność dyscyplinarna..., op. cit., s. 70.

${ }^{29}$ Wyrok TK z 8.12.1998, K 41/97, OTK ZU 1998, nr 7, poz. 117.

${ }^{30}$ Wyrok TK z 9.11.1993, K 11/93, OTK ZU 1993, nr 3, poz. 37.
} 
Poza funkcją ochronną wojskowa odpowiedzialność dyscyplinarna realizuje także funkcję integracyjną, która na gruncie odpowiedzialności karnej (z uwagi na sposób legislacji przepisów prawnokarnych a także sposób jej egzekwowania) w ogóle nie występuje.

Funkcja integracyjna wojskowej odpowiedzialności dyscyplinarnej przejawia się w zapewnieniu podmiotom wojskowej odpowiedzialności dyscyplinarnej autonomii w zakresie tworzenia norm postępowania, których są oni również adresatami. Innymi słowy, w skutek wyznaczania od wewnątrz pewnych standardów postępowania kolektywu wojskowego de facto dochodzi do występowania wewnętrznych mechanizmów samoregulacji. Warto zauważyć, że wskazane faktory - niezależności i samoregulacji, wspólnie tworzą wyznaczniki determinujące tożsamość kolektywu wojskowego, a także współtworzą standardy postępowania osób w nim zrzeszonych, tj. żołnierzy. Występowanie funkcji integracyjnej na płaszczyźnie wojskowej odpowiedzialności dyscyplinarnej pociąga za sobą konieczność wyjścia poza metody charakterystyczne dla tradycyjnej legislacji, polegające na określeniu w ustawie nakazów i zakazów, a następnie poddanie ich pod kognicję sądów (co jest właściwe dla odpowiedzialności karnej) ${ }^{31}$.

Odnosząc się do aspektu represyjności wojskowej odpowiedzialności dyscyplinarnej i odpowiedzialności karnej, stwierdzić należy, że co prawda charakteryzują się one pewną jej dozą, nie mniej jednak współczynnik ten ma różny wymiar. W ramach odpowiedzialności karnej, udział funkcji represyjnej jest znacznie wyższy niż przy wojskowej odpowiedzialności dyscyplinarnej, w której ustępuje on na rzecz funkcji: integracyjnej oraz ochronnej. Stan taki wynika ze sposobu legislacji wojskowych przepisów dyscyplinarnych.

Podczas gdy materialne podstawy wojskowej odpowiedzialności dyscyplinarnej są zazwyczaj ujęte bardzo lakonicznie ${ }^{32}$, to już w odniesieniu do możliwych form reakcji dyscyplinarnej mamy do czynienia z enumeratywnie wskazanym katalogiem kar i środków dyscyplinarnych ${ }^{33}$. Brak typizacji przewinień dyscyplinarnych skutkuje brakiem ich przyporządkowania względem określonych rodzajów kar dyscyplinarnych. Zastosowany w u.d.w. sposób legislacji wojskowych przepisów dyscyplinarnych jest możliwy z uwagi na quasi-represyjny charakter tejże odpowiedzialności. Inaczej sprawa wygląda na płaszczyźnie prawa karnego, gdzie do określonego typu przestępstwa przypisana jest określona forma/formy reakcji prawnokarnej - co w sposób bezpośredni zwraca uwagę na represyjny charakter prawa karnego.

Polaryzację między wojskową odpowiedzialnością dyscyplinarną a odpowiedzialnością karną widać również na płaszczyźnie podmiotów ferujących wyroki w sprawie. Represyjny charakter prawa karnego determinuje po pierwsze, by rozstrzygnięcia w sprawach karnych ferowały podmioty niezależne i bezstronne (tj. sędziowie), po drugie, konieczność zapewnienia systemu prawnej kontroli tychże rozstrzygnięć (poprzez zażalenie, apelację czy kasację).

\footnotetext{
${ }^{31}$ H. Izdebski, Granice prawa jako instrumentu ksztaltowania standardów zachowań w stużbie publicznej, [w:] A. Dębicka, M. Dmochowski, B. Kudrycka (red.), Profesjonalizm w administracji publicznej, Białystok 2004; zob.: P. Skuczyński, Nierepresyjne funkcje odpowiedzialności dyscyplinarnej a model postępowania w sprawach dyscyplinarnych, „Przegląd Legislacyjny” 2007, nr 3(101), s. 39 i n.

${ }^{32}$ Art. 17 u.d.w.

${ }^{33}$ Katalog kar dyscyplinarnych przepis art. 24 u.d.w., katalog środków dyscyplinarnych przepis art. 33 u.d.w.
} 
Wojskową odpowiedzialność dyscyplinarną sprawują natomiast osoby spośród kolektywu wojskowego (tj. przełożeni dyscyplinarni), czyli de facto osoby przynależące do tego samego środowiska, co obwiniony. Przełożony dyscyplinarny nie charakteryzuje się przymiotem niezawisłości właściwym dla sędziego orzekającego w sprawach karnych (i nie tylko). Co więcej, w przeciwieństwie do odpowiedzialności karnej wojskowa odpowiedzialność dyscyplinarna ma charakter wewnętrzny, tzn. odbywa się ona bez udziału kontroli z zewnątrz, zapadłe zaś orzeczenia dyscyplinarne opierają się nie tylko na podstawie normatywnej, lecz także na doświadczeniu wynikającym ze służby wojskowej, znajomości środowiska wojskowego czy innych elementach, takich jak postawa stron postępowania czy poziom zaufania społecznego do służby wojskowej.

Wojskowa odpowiedzialność dyscyplinarna skonkretyzowana jest zatem na integrację członków określonej zbiorowości oraz ochronę wartości relewantnych z punktu widzenia służby wojskowej. Stąd funkcję ochronną oraz integracyjną wojskowej odpowiedzialności dyscyplinarnej postrzegać należy jako konstytutywne, a nie deklaratoryjne (czyli stanowiące jedynie dodatek do funkcji represyjnej). Wojskowa odpowiedzialność dyscyplinarna jest właściwa jedynie dla określonego kolektywu, tj. wojska, przez co nie posiada ona powszechnego charakteru, czyli charakteru właściwego dla odpowiedzialności karnej. Dlatego między funkcjami wojskowej odpowiedzialności dyscyplinarnej a funkcjami odpowiedzialności karnej nie zachodzi znamię tożsamości.

\section{KILKA UWAG NA TEMAT RATIO LEGIS WOJSKOWEJ ODPOWIEDZIALNOŚCI DYSCYPLINARNEJ}

Pewnym uzasadnieniem dla konieczności utrzymania i egzekwowania wojskowej odpowiedzialności dyscyplinarnej (nawet w sytuacji jej zbiegu z odpowiedzialnością karną) jest $r a-$ tio legis stanowienia regulacji dyscyplinarnych w ogóle. Potrzeba stanowienia przepisów dyscyplinarnych wynika z konieczności utrzymania odpowiedniego poziomu społecznego zaufania wobec określonego rodzaju ,aktywności zawodowej” (w tym przypadku aktywności wynikającej ze służby wojskowej). Jak zauważono w jednym z wyroków TK, wypracowanie proceduralnych rozwiązań odpowiedzialności dyscyplinarnej: ,„...) i nadanie im - najpierw - pozasądowego charakteru, znajdować może podstawę w specyfice poszczególnych grup (...) oraz (....) [potrzebie ochrony] ich autonomii i samorządności”34. Co istotne, ,,poziom wymagań stawianych przedstawicielom zawodu związany jest z prestiżem danej profesji” ${ }^{\text {"35 }}$. Natomiast „odpowiedzialność dyscyplinarna (...) [poprzez obligowanie żołnierza] do należytego wykonywania swych obowiązków, stoi na straży prestiżu (...)"36. Dlatego zgodzić się należy ze stanowiskiem co do tego, że ,powszechnie stosowana klauzula, określająca (...) [przewinienie

\footnotetext{
${ }^{34}$ Wyrok TK z 8.12.1998, K 41/97, OTK 1998, nr 7, poz. 117.

${ }^{35}$ Wyrok TK z 11.09.2001, K 17/00, OTK 2001, nr 6, poz. 165.

${ }^{36}$ P. Przybysz, Prawo do sądu w sprawach dyscyplinarnych, PiP 1998, nr 8, s. 68.
} 
dyscyplinarne] jako zachowanie uchybiające godności (...) [służby wojskowej] wyraża istotę odpowiedzialności dyscyplinarnej"37.

Warunkiem sine qua non uznania określonego ,,zachowania” jako wojskowego przewinienia dyscyplinarnego jest uprzednie określenie katalogu wymagań stawianych względem członków danej formacji (w tym przypadku wobec żołnierzy). W następnej kolejności, trzeba rozpoznać, czy określone ,zachowanie” (żołnierza) godzi w prestiż przewidziany dla danego kolektywu (tj. wojska), czy też nie ${ }^{38}$.

Dlatego niewskazanie w u.d.w. katalogu wojskowych przewinień dyscyplinarnych postrzegać należy jako celowy zabieg legislacyjny, który (paradoksalnie) służy zapewnieniu należytego poziomu wykonywania obowiązków służbowych oraz pełnienia/odbywania służby wojskowej ${ }^{39}$.

Relewantną cechą wojskowej odpowiedzialności dyscyplinarnej (wskazaną na początku niniejszego opracowania) jest kwestia szeroko pojętej autonomii „dyscyplinarnej”. Autonomia ta przejawia się przede wszystkim w niezależności wojskowej odpowiedzialności dyscyplinarnej od odpowiedzialności karnej, co wynika expressis verbis z treści przepisu art. 17 ust. 1 u.d.w. oraz art. 17 ust. 2 pkt 2 i 3 u.d.w. O niezależności wojskowej odpowiedzialności dyscyplinarnej, a także postępowania w tym przedmiocie, świadczy okoliczność, że organ dyscyplinarny rozstrzygający w sprawie (tj. przełożony dyscyplinarny) nie bada, czy określone zdarzenie posiada znamiona przestępstwa, gdyż leży to w gestii sądów karnych. Bada jedynie (w sytuacji wszczęcia postępowania dyscyplinarnego w przedmiocie czynu, za który jego sprawca poniósł już odpowiedzialność karną), czy cele stawiane przed sankcją dyscyplinarną zostały osiągnięte wraz z wymierzeniem kary kryminalnej ${ }^{40}$.

Cele wojskowych form reakcji dyscyplinarnej nie są tożsame z celami stawianymi dla form reakcji prawnokarnej. Dlatego w doktrynie prawa karnego sensu largo w sposób wyraźny rozróżnia się formy reakcji prawnokarnej od wojskowych form reakcji dyscyplinarnej. Podnosi się, że istotą sankcji karnej jest zadanie dolegliwości sprawcy czynu przestępnego. Funkcją sankcji karnej jest odpłata, jej właściwością zaś jest retrospektywne ukierunkowanie, dlatego w zasadzie nie podlegają one uchyleniu ${ }^{41}$. Zdaniem M.A. Nowickiego kwalifikacja określonej

\footnotetext{
${ }^{37}$ Wyrok TK z 11.09.2001, K 17/00, OTK 2001, nr 6, poz. 165.

${ }^{38}$ Przy czym tworzone przepisy dyscyplinarne powinny czynić zadość standardom konstytucyjnym - w szczególności art. 42-45 i art. 78 Konstytucji; Wyrok TK z 8.12.1998, K 41/97, OTK 1998, nr 7, poz. 117. Zatem przepisy art. 42-45 i art. 78 Konstytucji mają zastosowanie przy odpowiedzialności karnoprawnej, mają również zastosowanie do każdego rodzaju postępowania represyjnego, także dyscyplinarnego; więcej zob.: J. Adamczyk, Postępowanie dyscyplinarne wobec studentów i doktorantów [w:] A. Szadok-Bratuń (red.), Nowe prawo o szkolnictwie wyższym a podmiotowość studenta, Wrocław 2007, s. 207; R. Sztyk, Odpowiedzialność dyscyplinarna notariuszy, Rejent 2005, nr 4, s. 139; wyrok TK z 16.11.1999, SK 11/99, OTK 1999, nr 7, poz. 158; wyrok TK z 11.12.2008, K 33/07, OTK-A 2007, nr 11, poz. 162; wyrok TK z 8.12.1998, K 41/97, OTK 1998, nr 7, poz. 117; wyrok TK z 19.03.2007, K 47/05, OTK-A 2007, nr 3, poz. 27.

${ }^{39}$ Wyrok TK z 27.02.2001, K 22/00.

${ }^{40}$ E. Zielińska, Odpowiedzialność zawodowa lekarza a odpowiedzialność karna, „Prawo i Medycyna” 1999, s. 66.

${ }^{41}$ Inaczej jest np. przy sankcjach egzekucyjnych, które powinny być uchylone w razie spełnienia obowiązku, dla którego przymusowego wykonania zostały ustanowione, a których zastosowanie w praktyce nie prowadzi do nałożenia nowych obowiązków, lecz do realizacji tych już wcześniej istniejących.
} 
formy reakcji jako formy reakcji prawnokarnej zależy m.in. od tego, by będące podstawą jej wymiaru prawo miało zastosowanie względem ogółu społeczeństwa, a nie jedynie do danej grupy charakteryzującej się określonym statusem ${ }^{42}$.

Dlatego wojskowych form reakcji dyscyplinarnych nie należy postrzegać w kategorii sankcji karnoprawnych. Pozbawienie wojskowej odpowiedzialności dyscyplinarnej cechy powszechności w konsekwencji pozbawia sankcje dyscyplinarne charakteru karnego ${ }^{43}$. Chociaż sankcje dyscyplinarne posiadają w sobie pewien element represyjności (co związane jest z naturą sankcji w ogóle), to nie współtworzą one katalogu sankcji karnych ${ }^{44}$.

Enumeratywnie wyliczone w przepisie art. 24 i 33 u.d.w. formy wojskowej reakcji dyscyplinarnej wywierają skutek jedynie na płaszczyźnie obwiniony-kolektyw, do którego on przynależy (tj. wojsko). To w sposób znaczący odróżnia wojskowe formy reakcji dyscyplinarnej od form reakcji prawnokarnej, które oddziałują na zewnątrz, tj. na relacje sprawcy z państwem oraz resztą społeczeństwa.

Zgodzić się należy z E. Kusowską co do tego, że: ,Zawarte w odpowiednich ustawach katalogi kar dyscyplinarnych, jakkolwiek uregulowane indywidualnie dla każdej grupy podmiotów podlegających odpowiedzialności dyscyplinarnej, wykazują pewien stopień podobieństwa. (...) Sankcje dyscyplinarne zostały odpowiednio uporządkowane w kolejności od najmniej do najbardziej dotkliwych, (...) [i co do zasady posiadają] one (...) charakter bądź społeczno-moralny (na przykład nagana, upomnienie), bądź związany ściśle z charakterem danej grupy (pozbawienie praw członka danej grupy (...) czasowe zawieszenie w prawach), natomiast kary godzące w sferę materialną ukaranego stanowią rzadkość" ${ }^{45}$.

Zatem praktyczne wyegzekwowanie wojskowej odpowiedzialności dyscyplinarnej nie jest przejawem represji karnej, lecz stanowi niezależne rozliczenie się wojska z żołnierzem, który swoim zachowaniem podważył autorytet i dobre imię całej formacji.

\section{Podsumowanie}

Limitacja wyrażona zasadą ne bis in idem statuuje zakaz podwójnego karania tego samego sprawcy za ten sam czyn, w tym samym celu. Dlatego jednoczesne lub sekwencyjne egzekwowanie dwóch różnych rodzajów odpowiedzialności w tym samym celu wobec sprawcy za de facto jeden jego czyn zawsze będzie okolicznością skłaniającą do dyskusji nad konstytucyjnością takiego rozwiązania.

Pytanie o poszanowanie standardów konstytucyjnych wynikających z zasady ne bis in idem z pewnością powoduje brzmienie przepisu art. 17 ust 1 u.d.w. i art. 17 ust 2 pkt 2-3 u.d.w.

\footnotetext{
${ }^{42}$ M. A. Nowicki, Europejski Trybunał Praw Człowieka. Orzecznictwo, t. I, Prawo do rzetelnego procesu, Zakamycze 2001, s. 28.

43 Ibidem, s. 29.

${ }^{44}$ M. Cieślak, Polskie prawo karne. Zarys systemowego ujęcia, Kraków 2011, s. 26.

${ }^{45}$ E. Kusowska, O postępowaniach dyscyplinarnych-uwagi na tle Uchwały Sądu Najwyższego I KZP18/12 z dnia 24 stycznia 2013, Adam Mickiewicz University Law Review, s. 161.
} 
Zgodnie z ich treścią żołnierz ponosi odpowiedzialność dyscyplinarną niezależnie od odpowiedzialności kreowanej na gruncie innych przepisów. Stąd żołnierz za czyn pozostający w związku z jego służbą może ponieść (jednocześnie lub sekwencyjnie) wojskową odpowiedzialność dyscyplinarną i np. odpowiedzialność karną.

Zauważyć należy, że zasada ne bis in idem statuuje zakaz podwójnego karania tego samego sprawcy za ten sam czyn, w tym samym celu. Z przeprowadzonej w niniejszym artykule analizy wynika wielopłaszczyznowy brak tożsamości zachodzący między odpowiedzialnością karną a wojskową odpowiedzialnością dyscyplinarną. Polaryzacja zauważalna jest nie tylko w odniesieniu do celów i funkcji tychże odpowiedzialności, lecz występuje także na płaszczyźnie form i celów stosowania poszczególnych rodzajów instrumentów reakcji karnej lub dyscyplinarnej.

Podczas gdy odpowiedzialność karna zapewnić ma ochronę społeczeństwa za pomocą wymierzenia sprawiedliwej odpłaty sprawcy czynu zabronionego za zło przez niego wyrządzone (co bezpośrednio zwraca uwagę na represyjny jej charakter), to wojskowa odpowiedzialność dyscyplinarna zmierza do zapewnienia ochrony kolektywu wojskowego za pomocą instrumentów oddziaływania dyscyplinarnego, które stosuje się w celu przede wszystkim wychowawczym i zapobiegawczym (art. 20 ust 1 u.d.w.). Zatem dolegliwość płynąca z tytułu zastosowania wojskowych środków dyscyplinarnych nie jest celem samym w sobie, lecz stanowi ona narzędzie do osiągnięcia celów zadekretowanych m.in. w przepisie art. 20 ust. 1 u.d.w. Dlatego uznać należy, że wojskowa odpowiedzialność dyscyplinarna posiada quasi-represyjny charakter.

Stąd jednoczesne lub sekwencyjne egzekwowanie odpowiedzialności karnej i wojskowej odpowiedzialności dyscyplinarnej wobec żołnierza, którego czyn będący wojskowym przewinieniem dyscyplinarnym realizuje także znamiona przestępstwa penalizowanego w k.k., nie narusza konstytucyjnej zasady ne bis in idem, gdyż każda ze wskazanych rodzajów odpowiedzialności realizuje inne cele i funkcje.

Uzasadnieniem dla takiego stanowiska jest również występująca na gruncie procesowym autonomiczna wykładnia przepisu art. 17 § 1 pkt 7 k.p.k. Zgodnie z jej brzmieniem negatywną przesłankę procesową wynikającą z zakazu ponownego karania za ten sam czyn odnieść należy jedynie do ,postępowania karnego" ${ }^{46}$, co z kolei w sposób jednoznaczny wyłącza z zakresu merytorycznego zasady ne bis in idem wojskowe postępowanie dyscyplinarne (nawet jeżeli postępowanie to prowadzone jest z zastosowaniem w sposób odpowiedni przepisów k.p.k.). Dlatego przyjąć należy, że prawomocny wyrok wydany w innym postępowaniu niż karne (np. w ramach wojskowej odpowiedzialności dyscyplinarnej) nie powoduje przeszkody do ponownej oceny stanu faktycznego z perspektywy odpowiedzialności karnej ${ }^{47}$, a tym samym nie stoi w opozycji do standardów konstytucyjnych gwarantowanych zasadą ne bis in idem.

\footnotetext{
${ }^{46}$ Zob.: C. Kulesza, Komentarz do art. 17 k.p.k. [w:] K. Dudka (red.), Kodeks postepowania karnego. Komentarz, Warszawa 2018, s. 76-78; J. Skorupka, Komentarz do art. 17 k.p.k., [w:] J. Skorupka (red.), Kodeks postepowania karnego. Komentarz, Warszawa 2021, s.76-79.

${ }^{47}$ Zob.: P. Hofmański, E. Sadzik, K. Zgryzek, Kodeks postępowania karnego. Tom I. Komentarz do art. 1-296, [w:] P. Hofmański (red.), Warszawa 2011, s. 190 i n.
} 
Konkludując (jednocześnie lub sekwencyjnie) egzekwowanie wobec żołnierza odpowiedzialności karnej i wojskowej odpowiedzialności dyscyplinarnej za jego przewinienie dyscyplinarne, które jednocześnie jest przestępstwem penalizowanym w k.k., nie stoi w opozycji do zasady ne bis in idem.

\section{BIBLIOGRAFIA}

\section{POZYCJE ZWARTE}

Adamczuk Justyna. 2007. Postępowanie dyscyplinarne wobec studentów i doktorantów. W Szadok-Bratuń Aleksandra (red.). Nowe prawo o szkolnictwie wyższym a podmiotowość studenta. Wrocław.

Błachnio-Parzych Anna 2016. Zbieg odpowiedzialności karnej i administracyjno-karnej jako zbieg reżimów odpowiedzialności represyjnej. Warszawa: Wolters Kluwer.

Cieślak Marian 1994. Polskie prawo karne. Zarys systemowego ujęcia. Warszawa: Wydawnictwo Naukowe PWN.

Cieślak Marian 2011. Polskie prawo karne. Zarys systemowego ujęcia. Kraków: Wydawnictwo Uniwersytetu Jagiellońskiego.

Giętkowski Radosław. 2013. Odpowiedzialność dyscyplinarna w prawie polskim. Gdańsk: Wydawnictwo Uniwersytetu Gdańskiego.

Hofmański Piotr, Sadzik Elżbieta, Zgryzek Kazimierz. 2011. Kodeks postępowania karnego. Tom I. Komentarz do art. 1-296. Warszawa: C.H. Beck

Izdebski Hubert. 2004. Granice prawa jako instrumentu kształtowania standardów zachowań w służbie publicznej. W Dębicka Anetta, Dmochowski Mariusz, Kudrycka Beata (red.), Profesjonalizm w administracji publicznej. Białystok.

Konarska-Wrzosek Violetta, Marek Andrzej. 2019. Prawo karne. Warszawa: C.H. Beck.

Kulesza Cezary. 2018. Komentarz do art. 17 k.p.k. W Dudka Katarzyna. (red.), Kodeks postepowania karnego. Komentarz. Warszawa.

Kusowska Ewelina. 2014. „O postępowaniach dyscyplinarnych - uwagi na tle Uchwały Sądu Najwyższego I KZP18/12 z dnia 24 stycznia 2013”, Adam Mickiewicz University Law Review.

Lachowski Jerzy, Marek Andrzej. 2018. Prawo karne. Zarys problematyki. Warszawa: Wolters Kluwer.

Leoński Zbigniew 1959. Odpowiedzialność dyscyplinarna w prawie Polski Ludowej. Poznań: Państwowe Wydawnictwo Naukowe. Skowron.

Łobocki Mieczysław. 2007. Wprowadzenie do metodologii badań pedagogicznych. Kraków: Oficyna Wydawnicza „Impuls”.

Morański Wojciech. 2013. „Charakter prawny odpowiedzialności dyscyplinarnej członka korpusu służby cywilnej”. Roczniki Administracji i Prawa. Rok XIII: 245-262

Nowicki Marek Antoni. 2001. Europejski Trybunał Praw Człowieka. Orzecznictwo, t. I, Prawo do rzetelnego procesu. Zakamycze, Kraków.

Przybysz Piotr. 1998. Prawo do sądu w sprawach dyscyplinarnych. PiP 1998, nr 8.

Rogalski Maciej. 2005. Odpowiedzialność dyscyplinarna prokuratorów a odpowiedzialność karna. Zagadnienia wybrane. W Zięba-Załucka Halina (red.), Kijowski Maciej (red.) Godność obywatela, urzędu i instytucji. Zmiany ustrojowe Prokuratury RP. Rzeszów. 
Skorupka Jerzy. 2021. Komentarz do art. 17 k.p.k. W Skorupka Jerzy. (red.), Kodeks postepowania karnego. Komentarz. Warszawa.

Skuczyński Paweł. 2007. „Nierepresyjne funkcje odpowiedzialności dyscyplinarnej a model postępowania w sprawach dyscyplinarnych”. Przegląd Legislacyjny 3(101): 35-53.

Skuczyński Paweł. 2008. Granice odpowiedzialności dyscyplinarnej. W Skuczyński Paweł., Zawadzki Piotr, Odpowiedzialność dyscyplinarna. Podstawy, procedura i orzecznictwo w sprawach studentów Uniwersytetu Warszawskiego 2000-2005. Warszawa.

Sztyk Romuald. 2005. „Odpowiedzialność dyscyplinarna notariuszy”. Rejent 4(168): 139-161. Zielińska Eleonora. 1999. „Odpowiedzialność zawodowa lekarza a odpowiedzialność karna”. Prawo i Medycyna 1: 61-76.

Ziółkowska Agata. 2020. Odpowiedzialność karna a odpowiedzialność dyscyplinarna w wojsku zagadnienia materialnoprawne I. Warszawa: Instytut Wydawniczy EuroPrawo.

\section{AKTY PRAWNE}

Dekret z 26 czerwca 1945 r., Wojskowe przepisy dyscyplinarne, Dz. U. 1945, nr 37, poz. 219 Regulamin Dyscyplinarny Sił Zbrojnych PRL z 1959 r., zatwierdzony i wprowadzony w życie rozkazem Ministra Obrony Narodowej nr 30/MON z 28 lipca 1959 r.

Ustawa z 21 maja 1963 r., o dyscyplinie wojskowej oraz o odpowiedzialności żołnierzy za przewinienia dyscyplinarne i za naruszenia honoru i godności żołnierskiej, Dz. U. 1963, nr 22, poz. 114

Regulamin Dyscyplinarny z 1963 r., zatwierdzony i wprowadzony w życie rozkazem Ministra Obrony Narodowej nr 57/MON z 19 października 1963 r.

Ustawa z 06.04.1990, o Policji, t.j. Dz.U. 2021, poz. 1882.

Ustawa z 12.10.1990, o Straży Granicznej, t.j. Dz.U. 2021, poz. 1728.

Ustawa z 24.08.1991, o Państwowej Straży Pożarnej, t.j. Dz.U. 2021, poz. 1728.

Ustawa z 2.04.1997, Konstytucja Rzeczypospolitej Polskiej, t.j. Dz.U. 2009, poz. 946

Ustawa z 06.06.1997, Kodeks karny, t.j. Dz.U. 2021, poz. 1023.

Ustawa z 06.06.1997, Kodeks postępowania karnego, t.j. Dz.U. 2021, poz.1023.

Ustawa z 24.05.2002, o Agencji Bezpieczeństwa Wewnętrznego oraz Agencji Wywiadu, t.j. Dz.U. 2020, poz. 2320.

Ustawa z 09.06.2006, o służbie funkcjonariuszy Służby Kontrwywiadu Wojskowego oraz Służby Wywiadu Wojskowego, t.j. Dz.U. 2021, poz. 1362.

Ustawa z 09.06.2006, o Centralnym Biurze Antykorupcyjnym, t.j. Dz.U. 2021, poz. 1671.

Ustawa z 09.10.2009, o dyscyplinie wojskowej, t.j. Dz.U. 2021, poz. 1489.

Ustawa z 09.04.2010, o Służbie Więziennej, t.j. Dz. U. 2021, poz. 1728.

\section{ORZECZNICTWO}

Wyrok TK z 9.11.1993, K 11/93, OTK ZU 1993, nr 3, poz. 37.

Wyrok TK z 8.12.1998, K 41/97, OTK ZU 1998, nr 7, poz. 117.

Wyrok TK z 16.11.1999, SK 11/99, OTK 1999, nr 7, poz. 158.

Wyrok TK z 27.02.2001, sygn. K. 22/00, OTK ZU 2001, nr 3.

Wyrok TK z 11.09.2001, K 17/00, OTK 2001, nr 6, poz. 165.

Wyrok TK z 8.10.2002, sygn. K 36/00, OTK-A 2002, z. 5, poz. 63. 
Wyrok WSA w Warszawie z 15.04.2004, II SA/Wa 1561/03, LEX nr 150843.

Wyrok TK z 3.11.2004, sygn. K 18/03, OTK-A 2004, z. 10, poz. 103.

Wyrok WSA w Warszawie z 17.01.2006, II SA/Wa 1755/05, LEX nr 194440.

Wyrok WSA w Warszawie z 15.11.2006, II SA/Wa 1344/06.

Wyrok TK z 19.03.2007, K 47/05, OTK-A 2007, nr 3, poz. 27.

Wyrok TK z 11.12.2008, K 33/07, OTK-A 2007, nr 11, poz. 162. 